\title{
Highly divergent cuticular hydrocarbon profiles in the cleptobiotic ants of the Ectatomma ruidum species complex
}

\section{Kenzy I. Peña-Carrillo ${ }^{1,2}$, Chantal Poteaux ${ }^{1}$, Chloé Leroy ${ }^{1}$, Rubí N. Meza-Lázaro ${ }^{3}$, Jean- Paul Lachaud $^{4,5}$, Alejandro Zaldívar-Riverón ${ }^{3}$, Maria Cristina Lorenzi ${ }^{1}$}

${ }^{1}$ LEEC-Laboratoire d'Ethologie Expérimentale et Comparée, Université Sorbonne Paris Nord, Sorbonne Paris Cité, 99 avenue J.-B. Clément, 93430 Villetaneuse, France.

${ }^{2}$ INIFAP, Campo Experimental General Terán, km 31 carretera Montemorelos-China, 67400, General Terán, N.L. México.

${ }^{3}$ Colección Nacional de Insectos, Instituto de Biología, Universidad Nacional Autónoma de Mexico, 3er. circuito exterior s/n, Cd. Universitaria, Copilco Coyoacán A. P. 70-233, C. P. 04510, Ciudad de México, México.

${ }^{4}$ Depto. de Conservación de la Biodiversidad, El Colegio de la Frontera Sur, Avenida Centenario Km. 5.5, 77074 Chetumal, Quintana Roo, México.

${ }^{5}$ Centre de Recherches sur la Cognition Animale, Centre de Biologie Intégrative, Université de Toulouse CNRS, UPS, 118 route de Narbonne, 31062 Toulouse Cedex 09, France.

Corresponding author: kenzy.p@gmail.com; pena.kenzy@inifap.gob.mx 


\begin{abstract}
In social insects, chemical communication is the main communication mode among colony members, which use the blends of cuticular hydrocarbons as recognition cues to discriminate between nestmates and non-nestmates and to prevent the exploitation of their nest resources by aliens. The aim of this study was to assess the variation of nestmate recognition cues in the ant Ectatomma ruidum, a species complex with a considerably conserved morphology and one of the few ant species where intraspecific thievery, a form of cleptoparasitism, has been reported. We analyzed the cuticular hydrocarbon profiles of ants collected from a number of geographically separated populations, and examined DNA sequence data to assess their species identity. We focused on one species of the complex, E. ruidum sp. 3-4, whose species delineation remains controversial. We documented that several quantitative and qualitative traits of the cuticular hydrocarbon profiles varied significantly between populations, indicating that this species harbors more cuticular chemical phenotypic diversity than expected within a single species. In particular, there was a striking divergence among populations in the proportion of methylalkanes, alkenes, alkadienes and odd-chain components, which likely play a major role in nestmate/non-nestmate discrimination, a process which might have been crucial in these cleptobiotic ants. Further investigations are needed to test the hypothesis that biotic pressures, such as the need to discriminate conspecific intruders and limit thievery, could have played an important role in promoting the evolutionary divergence between populations in this ant species complex.
\end{abstract}

Keywords: biotic interactions, chemical divergence, nestmate recognition cues, species complex, thievery. 


\section{Introduction}

Recognition of group members has favored the evolution and maintenance of sociality (Hamilton 1987; d'Ettorre and Lenoir 2010). Albeit social insects communicate in different forms, chemical communication is the main communication mode among colony members, allowing them to exchange different kinds of information (Wyatt 2014; Leonhardt et al. 2016). Among the different contents that a chemical message can encode, social insects use the blend of hydrocarbons they bear on their cuticle as a chemical signature that conveys information about castes, task specialization and reproductive status (Blomquist and Bagnères 2010). Cuticular hydrocarbons also allow social insects to discriminate between nestmates and non-nestmates, and prevent exploitation of nest resources by aliens (van Zweden and d'Ettorre 2010; Leonhardt et al. 2016). Indeed, when social insects encounter another individual, the presence of sufficiently large differences between their cuticular hydrocarbon profiles can trigger aggressive behavioral responses and allows colony residents to reject intruders (Dani et al. 2001; Martin et al. 2008; van Zweden and d'Ettorre 2010).

In insects, cuticular hydrocarbon mixtures are usually composed of different hydrocarbon classes, such as linear alkanes ( $n$-alkanes), alkanes with one or more methyl branches (mono-, di-, tri-, tetra-methylalkanes) and hydrocarbons with one or two unsaturations, alkenes and alkadienes (Blomquist and Bagnères 2010). Usually, quantitative variations of the same set of hydrocarbons discriminate between colonies (intraspecific differences), whereas different species have qualitatively different profiles, even among closely related taxa (Hölldobler and Michener 1980; van Zweden and d'Ettorre 2010). Cuticular hydrocarbons are typically species-specific and qualitatively stable across the entire species distribution range (Lockey and Metcalfe 1988; Drijfhout et al. 2009; Guillem et al. 2016). Consequently, they are considered as useful taxonomic tools for species delimitation (Bagnères and Wicker-Thomas 2010; Kather and Martin 2012). For instance, cuticular hydrocarbons allowed to separate Myrmica sabuleti from M. scabrinodis, two species that are morphologically extremely similar but differ chemically in the composition of their cuticular layers, in particular in the presence of specific methylalkanes, which thus can serve as accurate diagnostic characters (Guillem et al. 2012). Studies focused on species such as Formica japonica (Akino et al. 2002), Neoponera (=Pachycondyla) villosa (Lucas et al. 2002), Tetramorium caespitum/impurum complex (Schlick-Steiner et al. 2006), Crematogaster levior and Camponotus femoratus (Hartke et al. 2019) are other examples of ant taxa with confirmed cryptic diversity that was discovered after examining their cuticular hydrocarbon profiles. Cuticular hydrocarbon analyses have also recently highlighted that sympatric, cryptic species exist in $\mathrm{Cr}$. levior and $\mathrm{Ca}$. femoratus, two neotropical ant species that exhibit parabiotic association, a lifestyle which might have promoted chemical divergence (Hartke et al. 2019).

Ectatomma ruidum Roger is a mainly Neotropical, widely distributed ant taxon that is likely to include a cryptic species diversity, which only has been recently started to be unveiled. Two recent studies based on mitochondrial (mt) and nuclear DNA sequence data and morphological evidence revealed that this taxon actually represents a species complex (Aguilar-Velasco et al. 2016; Meza-Lázaro et al. 2018), though its species delineation still remains unclear. In the first of these studies, morphological data indicated the existence of four morphospecies, two of which apparently are widespread along the Neotropics (E. ruidum spp. 1 and 2), whereas the remaining two species (E. ruidum spp. 3 and 4) and a presumably hybrid population (E. ruidum sp. 2 × 3 ) are restricted to few localities in Oaxaca, southeast 
Mexico. These results became more complicated with the subsequent discovery of extensive heteroplasmy (i.e. presence of multiple mtDNA haplotypes in a single organism; Magnacca and Brown 2010) in specimens of the morphospecies E. ruidum spp. 3, 4 and $2 \times 3$ which might represent a single species whose populations share heteroplasmy (Meza-Lázaro et al. 2018).

E. ruidum, as currently known, is unique in a behavioral trait named intraspecific cleptobiosis. Besides the "normal" foraging behavior, some colony members display an alternative, parasitic, foraging strategy that consists of visiting conspecific colonies to take food from inside the nest and bringing it back to their home colony (Breed et al. 1990; De Carli et al. 1998). During foraging, thief ants exhibit a peculiar behavior: unlike other foragers, during their travel home they do not always follow a narrow path to their colony, and often hide (Jandt et al. 2015). Thieves also differ from other foragers in their cuticular chemical profile, which is significantly poorer in hydrocarbons (Jeral et al. 1997), and have been proposed as a distinct caste of foragers (McGlynn et al. 2015). This behavior has been reported in different locations along the distribution range of E. ruidum (De Carli et al. 1998, Breed et al. 1999), but its relation with the taxonomic complexity of the species remains unclear.

The intriguing complexity for species identification within the E. ruidum complex, coupled with its cleptobiotic behavior make it an ideal model system to study variation in recognition cues, as parasitic relationships have been identified as potential evolutionary drivers of polymorphism in these cues (Crozier 1986). These results might also contribute to future integrative taxonomy approaches where data from multiple sources (i.e. morphology, genetic analyses, ecological niche modeling, chemical analyses, etc.) are useful to identify or define species boundaries (Heethoff et al. 2011; Steiner et al. 2018). Here we compared the cuticular hydrocarbon profiles within the E. ruidum complex. Specifically, we tested for the intraspecific variation of the cuticular hydrocarbon profiles between populations of E. ruidum sp. 3-4 from southeast Mexico, whose boundaries remain controversial (Aguilar-Velasco et al. 2016; Meza-Lázaro et al. 2018). 


\section{Material and methods}

\section{Study model}

Ectatomma ruidum is an earth-dwelling ant that occurs in a wide range of habitats in Neotropics, including plantations and damp forests, from sea level up to $1600 \mathrm{~m}$ (McGlynn et al. 2015; Aguilar-Velasco et al. 2016). Typically, E. ruidum nests have a single entrance and contain between 50 and 200 individuals (Lachaud 1985) and their densities can be very high (up to 11200 nests per hectare, Schatz and Lachaud 2008). These ants have a very generalist diet and the foraging activity is mainly diurnal (Lachaud 1990). In general, colonies are monogynous but in some regions they are facultatively polygynous with size-dimorphic queens (macro and microgynes) (Lachaud et al. 1999).

\section{Collection of ants}

We collected E. ruidum colonies in the populations Cozoaltepec, Huaxpaltepec, Punto 3, Río Grande and Santo Domingo de Morelos along a transect of $150 \mathrm{~km}$ across the Pacific coastal zone in the state of Oaxaca, México, in order to increase the sampling area covered by Aguilar-Velasco et al. (2016) (populations Coyula, Mazunte, Piedras Negras, Puerto Escondido). We also collected ants in two additional populations, one $500 \mathrm{~km}$ far from Coyula, Oaxaca to the south Pacific coast in Cantón Leoncillos, Chiapas, Mexico, and the remaining one in Cali, Colombia (Fig. 1 and Table 1); the ants from Cali, Canton Leoncillos, Coyula, Mazunte, Piedras Negras and Puerto Escondido belong to the same sampling as that in Aguilar-Velasco et al. (2016) and Meza-Lázaro et al. (2018). Colonies from the same population were at least $2 \mathrm{~m}$ distant from each other. In Oaxaca and Chiapas, Mexico, the climate is hot and semi-humid to semi-dry with tropical deciduous and semi-deciduous forests (Rzedowski 2006). Ants in Mexico were collected in plantations or forest, whereas in Colombia, they were collected in the urban area.

\section{Species identification}

We identified the ants from Cozoaltepec, Huaxpaltepec, Punto 3, Río Grande, and Santo Domingo de Morelos based on the diagnostic morphological features of the species E. ruidum mentioned by Kugler and Brown's (1982) and Arias-Penna's (2008) keys to species of Ectatomma. For their molecular characterization, we sequenced the barcoding region, which is a fragment of the cytochrome oxidase I (COI) mtDNA gene. We also included in the molecular analyses previously published sequences of ants from Cali, Cantón Leoncillos, Coyula, Mazunte, Puerto Escondido and Piedras Negras (Aguilar-Velasco et al. 2016; MezaLázaro et al. 2018). All newly generated sequences were obtained following the laboratory procedures, primers and PCR programs mentioned by Aguilar-Velasco et al. (2016) (Table 1). The specimens that were sequenced in the current study were deposited in the National Collection of Insects (CNIN) at the National Autonomous University of Mexico (UNAM), Mexico, and the National Natural History Museum (MNHN) in Paris, France.

To confirm the taxonomical identification, we conducted a Maximum Likelihood (ML) analysis using the program RAxML version 8 (Stamatakis 2014) to reconstruct the phylogenetic relations among representative specimens (workers) of all the examined populations of the E. ruidum complex. We used the GTRCAT model of sequence evolution and partitions based on codon position, and bootstrap support values were generated with 1000 rapid bootstrap replicates. ML analyses were carried out in the CIPRES Science 
Gateway v. 3.3 (Miller et al. 2010) portal. In case it was not possible to assign ants to any of the previously proposed morphospecies we used the putative species assignation of MezaLázaro et al. (2018) based on mitogenome information. In Meza-Lázaro et al. (2018), all the seven individuals of E. ruidum spp. 3 and 4 that were examined were heteroplasmic with highly divergent mitochondrial haplotypes $(1.88-5.81 \%$ polymorphic sites spread across their genomes). 
Fig. 1 Map showing the examined populations of the E. ruidum species complex 


\section{Chemical analyses}

A total of 130 foragers collected from the foraging area were used for the chemical analyses (five ants per colony, with the exception of Huaxpaltepec with nine ants per colony, and Santo Domingo de Morelos, with six ants in one of the colonies) (Table 1). Ants were killed by freezing them in individual tubes at $-20{ }^{\circ} \mathrm{C}$ after their arrival to the laboratory. The extracts of their cuticular hydrocarbons were obtained by dipping each ant separately in $100 \mu \mathrm{l}$ of pentane supplemented with an internal standard $\left(\mathrm{C}_{18}\right.$ at $\left.5 \mathrm{ng} / \mu \mathrm{l}\right)$ for $20 \mathrm{~min}$. The extracts were then dried and re-diluted in $20 \mu 1$ of pentane before use.

We injected $2 \mu \mathrm{l}$ of the extract in a 7890A Gas Chromatograph (Agilent Technologies, Santa Clara, CA, USA), equipped with an HP-5MS capillary column $(30 \mathrm{~m} \times 250 \mu \mathrm{m} \times 0.25$ $\mu \mathrm{m})$ and a splitless injector, coupled to a 5975C Mass Spectrometer (Agilent Technologies) with $70 \mathrm{eV}$ electron impact ionization. The carrier gas was helium at a constant flow of 1 $\mathrm{ml} / \mathrm{min}$. The temperature program was as follows: an initial hold at $70^{\circ} \mathrm{C}$ for $1 \mathrm{~min}$, then 70 $200^{\circ} \mathrm{C}$ at $30^{\circ} \mathrm{C} / \mathrm{min}$, then $200-300^{\circ} \mathrm{C}$ at $3^{\circ} \mathrm{C} / \mathrm{min}$, then $300-320^{\circ} \mathrm{C}$ at $20^{\circ} \mathrm{C} / \mathrm{min}$, then hold at $320^{\circ} \mathrm{C}$ for $3 \mathrm{~min}$. Peaks areas were integrated with the MSD ChemStation software E.02.01.1177 (Agilent Technologies).

Hydrocarbons were identified based on diagnostic ions and mass spectra and compared with entries of the mass spectral library in NIST 2014 to known standards. We calculated relative abundances of hydrocarbons as ion count proportions with respect to total ion-count in the chromatogram. Thirty-one peaks were not identified because at trace levels. These unknown hydrocarbons were used for the visual representation of proportions of different classes of cuticular hydrocarbons, but were excluded from the statistical analyses.

\section{Statistical analyses}

In general, the chemical profiles of the ants of the E. ruidum species complex consisted of large numbers of very small peaks between 23 and 37 carbon atoms. Individuals from each population had both shared and population-specific hydrocarbons, which were absent in individuals from the other populations. The high number of hydrocarbons (i.e., variables) and the high number of zeros in the whole dataset of the relative abundances (population-specific hydrocarbons absent from most populations) made most statistical analyses inappropriate. Moreover, both qualitative and quantitative data are relevant when comparing the chemical profiles of different species, especially if information (e.g., colony identity) is mainly encoded in quantitative traits (Menzel et al. 2017a). Therefore, we built a simplified chemical profile of each ant which on one side reduced the number of variables for the analyses, and on the other included quantitative compositional data. For this, we grouped the hydrocarbons with the same carbon-chain length (i.e., same number of carbon atoms) by class as described by Elmes et al. (2002). For each chain length between 23 and 37 carbon atoms, we calculated the total percentage of $n$-alkanes, alkenes, alkadienes, methylalkanes and dimethylalkanes. The simplified chemical profiles contained 53 variables with a maximum of 5 variables per chain length (e.g., for the chain length of 25 carbon atoms, we calculated the percentage of $n$-C25, $\mathrm{C} 25: 1, \mathrm{C} 25: 2$, methyl-C25, dimethyl-C25 and so on for any chain length). We used the simplified chemical profiles for all statistical and exploratory analyses.

We made detailed statistical analyses of the E. ruidum sp. 3-4 from Mazunte, Puerto Escondido and Piedras Negras (Oaxaca, $\mathrm{n}=40$ ants, with at least two colonies per 
population). In order to investigate the amount of chemical variation among these ants we analyzed nine different traits in their cuticular chemical profiles: 1-2) NMDS scores (axis 1 and 2);3) median chain length; 4-8) proportion of hydrocarbon classes and 9) overall proportion of hydrocarbons with an odd number of carbon atoms.

The nine traits were calculated as follows.

The NMDS scores were obtained by performing a non-parametric, descriptive analysis running Nonmetric Multidimensional Scaling (NMDS). We ran a NMDS whose scores were used to perform a further analysis (see below). In this analysis, we used the Bray-Curtis distance measures of the relative abundance of the (untransformed) simplified ant chemical profiles. We calculated the median chain length by computing the percentage of hydrocarbons for each chain length and we identified the median chain length as the lowest chain length where the cumulative sum of percentages was $\geq 50 \%$ (Menzel and Schmitt 2012; Menzel et al. 2017a; Menzel F. pers. comm.). We also determined the proportion of odd-chain (vs even) hydrocarbons in the chemical profile. Finally, we summarized the variation in the chemical profile of E. ruidum sp. 3-4 by entering the following traits in a Principal Component Analysis (PCA, variables standardized via correlation matrix, Varimax rotation): NMDS scores for axes 1 and 2, median chain length, proportion of the five hydrocarbon classes and overall proportion of odd-chain hydrocarbons.

We tested for differences in each chemical trait separately and in the PCs summarizing the E. ruidum sp. 3-4 ant chemical variation by running Generalized Linear Mixed Models (GLMMs) for normally distributed data (identity link), where traits were the response variables, population was the fixed factor and colony the random factor to account for the non-independence of data from ants of the same origin.

We performed a second NMDS on the complete dataset $(n=130$ ants from the 11 populations) to explore the amount of chemical variation within the whole E. ruidum species complex (Bray-Curtis distance measures of the relative abundance of the simplified cuticular profiles). The small number of colonies sampled per population did not allow for statistical analyses on this data set.

All statistical analyses were conducted with the software IBM SPSS version 23. The NMDS was performed in PAST (Paleontological Statistics, version 3.25) (Hammer et al. 2001). If not stated otherwise, descriptive values are given as mean \pm standard errors. 


\section{Results}

\section{Species assignation}

The phylogram derived from the ML analysis is given in Supplementary Material 1. Based on the clades that were recovered and on our morphological examination, we could not assign ant workers from Cozoaltepec, Punto 3 and Río Grande neither to E. ruidum sp. 3 nor sp.4. We therefore consider all populations from Oaxaca belonging to E. ruidum sp. 3-4 as a single putative species. Ants from Santo Domingo de Morelos were assigned to E. ruidum sp. 2. We could not assign the ants from Huaxpaltepec to any of the previously proposed putative species based on molecular data and thus we provisionally considered them as E. ruidum sp. 5. For the rest of populations, species identification is available in Table 1. 
Table 1 Collection sites of the Ectatomma ruidum ants.

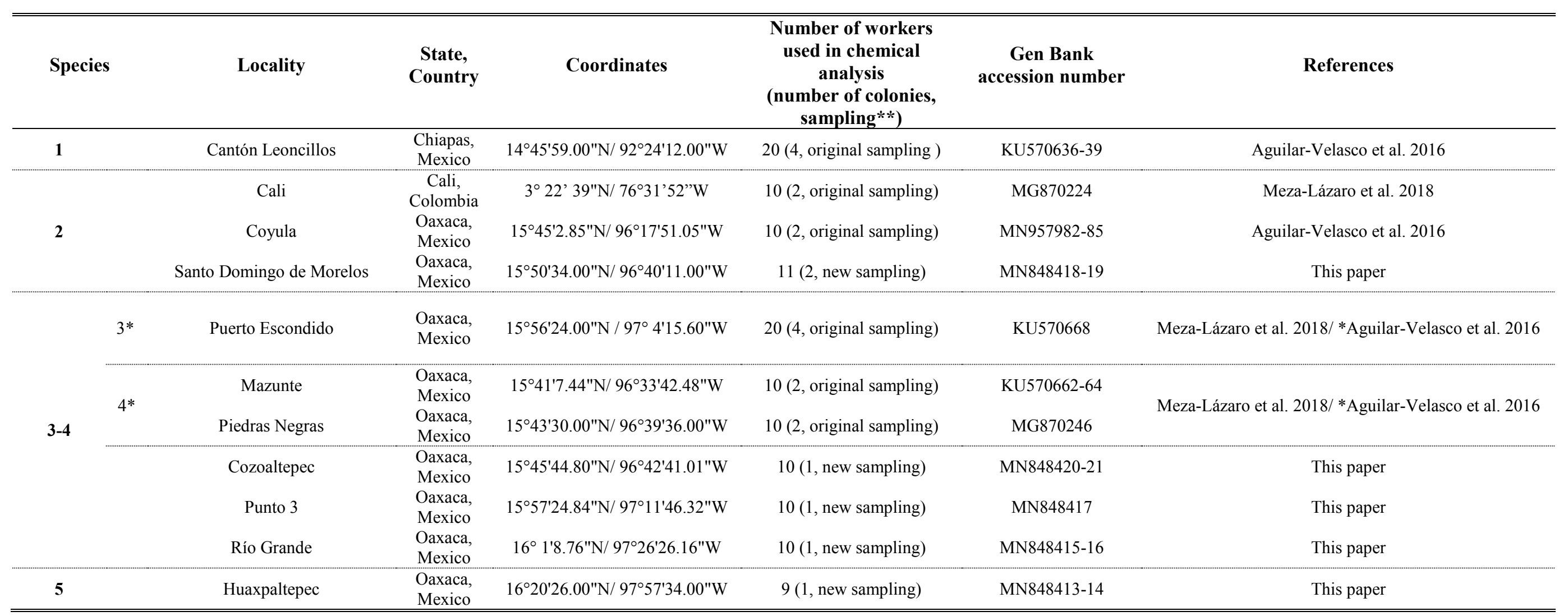

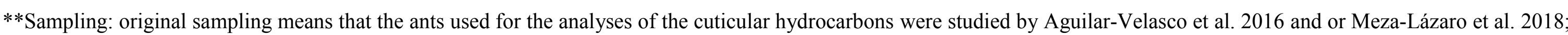
new sampling refers to the newly collected ants. 


\section{Chemical profile of the ants $E$. ruidum sp. 3-4 and median chain length}

The chemical profiles of E. ruidum sp. 3-4 from Mazunte, Piedras Negras and Puerto Escondido comprised 75, 74 and 61 peaks, respectively, and they were separated in the NMDS plot (Fig. 2). Ants from Piedras Negras had variable and mainly negative values in NMDS axis 1, while those from Puerto Escondido only had positive values. While the ants from Mazunte had intermediate values in NMDS axis 1, they were fairly well differentiated from the others in the NMDS axis 2 (Fig. 2).

The median chain length of the cuticular hydrocarbons varied from 26 to 30 carbon atoms.

Fig. 2 Two-dimensional Nonmetric Multidimensional Scaling ordination of the chemical profiles of E. ruidum sp. 3-4

\section{Variation in the classes of hydrocarbons within $E$. ruidum sp. 3-4}

The differences in the proportions of alkadienes, alkenes and methyl-branched alkanes were highly significant among the populations Mazunte, Puerto Escondido and Piedras Negras (alkadienes $\mathrm{F}_{2,37}=3.798, \mathrm{P}=0.032$; alkenes: $\mathrm{F}_{2,37}=21.628, \mathrm{P}<0.0001$; methyl-branched alkanes $F_{2,37}=18.960, P<0.0001$ ) (Fig. 3). In contrast, the proportions of linear alkanes and dimethyl branched alkanes did not differ significantly (linear alkanes $\mathrm{F}_{2,37}=1.308, \mathrm{P}=0.283$; dimethyl branched alkanes $\mathrm{F}_{2,37}=1.810, \mathrm{P}=0.178$ ).

All ants had chemical profiles extremely rich in odd-chain hydrocarbons (grand mean: 89.5\% \pm 0.3 ; Piedras Negras: $92.5 \pm 0.5$, Puerto Escondido: $89.5 \pm 0.2$, and Mazunte: $86.8 \pm$ $0.6)$, but their proportions significantly differed by population $\left(\mathrm{F}_{2,37}=30.166, \mathrm{P}<0.0001\right)$ (Fig. 3). There were significant differences between populations in the proportions of oddchain methylalkanes $\left(\mathrm{F}_{2,37}=18.960, \mathrm{P}<0.000\right)$, alkenes $\left(\mathrm{F}_{2,37}=21.628, \mathrm{P}<0.000\right)$, alkadienes $\left(\mathrm{F}_{2,37}=3.798, \mathrm{P}=0.032\right)$. There were no significant differences in the proportions of odd-chain dimethylalkanes $\left(\mathrm{F}_{2,37}=1.810, \mathrm{P}=0.178\right)$ and linear alkanes $\left(\mathrm{F}_{2,37}=1.308, \mathrm{P}\right.$ $=0.283$ ).

Fig. 3 Mean proportions of: a) cuticular hydrocarbons and b) odd-chain hydrocarbons of ants E. ruidum sp. 3-4 by class

\section{PCA on the chemical traits within E. ruidum sp. 3-4}

The variation of the chemical profiles of the ants assigned to E. ruidum sp. 3-4 was summarized in two principal components that together explained $76.7 \%$ of the total variance. PC1 values (56.6\% variance explained) discriminated among the three populations (GLMM, $\left.\mathrm{F}_{2,37}=10.649, \mathrm{P}<0.0001\right)$. At one extreme of PC1 variation, the ants from Piedras Negras presented the highest proportions of alkenes and alkadienes (Table 2), whereas on the other extreme, ants from Puerto Escondido and Mazunte presented the highest values of NMDS axis 1 and the highest proportions of methylalkanes and dimethylalkanes (Table 2). With respect to PC2 (20.1\% variance explained), the ant profiles significantly differed by population $\left(\mathrm{F}_{2,37}=29.032, \mathrm{P}<0.0001\right)$, with those from Mazunte having higher NMDS axis 2 scores and larger proportion of $n$-alkanes than those from Piedras Negras and Puerto Escondido (Table 2, Fig. 4). 
Table. 2 Scores of the PCA factor loadings on the nine chemical traits (in bold only $r>$ 0.700). The peaks are sorted by loading size. High loadings indicated that the trait was highly correlated with the PC.

\begin{tabular}{lcc}
\hline \hline \multicolumn{1}{c}{ Rotated Component Matrix } & \multicolumn{2}{c}{ Principal Component } \\
\cline { 2 - 3 } & 1 & 2 \\
\hline NMDS axis1 scores & $\mathbf{0 . 9 7 1}$ & -0.071 \\
Proportion of methylalkanes & $\mathbf{0 . 9 6 2}$ & -0.102 \\
Proportion of alkenes & $\mathbf{0 . 9 6 1}$ & -0.126 \\
Proportion of alkadienes & $\mathbf{- 0 . 8 2 7}$ & -0.179 \\
Proportion of dimethylalkanes & $\mathbf{0 . 8 0 8}$ & -0.058 \\
Median chain length & 0.654 & 0.456 \\
NMDS axis 2 scores & -0.068 & $\mathbf{0 . 8 4 0}$ \\
Proportion of $\boldsymbol{n}$-alkanes & -0.214 & $\mathbf{0 . 7 0 5}$ \\
Proportion of odd chain hydrocarbons & -0.589 & -0.690 \\
\hline \hline
\end{tabular}

Fig. 4 The PCA's plot of the nine traits describing the cuticular hydrocarbon profiles of ants of E. ruidum sp. 3-4

\section{Exploratory analysis of the chemical profiles in the $E$. ruidum species complex}

The chemical profiles of the ants of E. ruidum sp. 3-4 had 64 peaks in Cozoaltepec and 58 in Punto 3 and Rio Grande. Ants of E. ruidum sp. 2 from Cali, Colombia, and Coyula and Santo Domingo de Morelos, Mexico, had 53, 50 and 42 hydrocarbon peaks, respectively, whereas the ones assigned to E. ruidum sp. 1 from Cantón Leoncillos, had 46 peaks. There were 55 peaks in the chemical profiles of the ants E. ruidum sp. 5 from Huaxpaltepec. Overall, we identified 12 alkadienes, 23 alkenes, $10 n$-alkanes, 37 methylalkanes, 50 dimethylalkanes (Supplementary material 2). Including 31 peaks that could not be identified (unknown hydrocarbons), we had a total of 163 hydrocarbon peaks in the whole data set of E. ruidum.

The NMDS analysis performed on the simplified chemical profiles of the whole data set suggested that extensive variation might exist both within and between the putative species (E. ruidum sp. 1, sp. 2, sp. 3-4 and sp. 5) that have been proposed for the complex (Fig. 5), though no statistical analysis could be done due to the limited sample size. With respect to $E$. ruidum sp. 3-4, ants from Río Grande and Cozoaltepec appear as chemically distant from those of Mazunte, Puerto Escondido, Piedras Negras and Punto 3 (high negative values in NMDS axis 2). Within the E. ruidum sp. 2 samples, those from Santo Domingo de Morelos may differ from those from Coyula and Cali on the NMDS axis 1, while ants from Cali may differ from the ants of Santo Domingo de Morelos and Coyula on the NMDS axis 2.

Fig. 5 Two-dimensional Nonmetric Multidimensional Scaling ordination of the chemical profiles of the E. ruidum species complex 



\section{Discussion}

The current results show striking divergences in quantitative and qualitative components in the chemical profiles of E. ruidum sp. 3-4 ant populations. Such chemical divergence largely exceeds the current taxonomic delimitation based on molecular data (Meza-Lázaro et al. 2018), indicates high intraspecific diversity within E. ruidum sp. 3-4 and highlights the need for integrative taxonomic studies. The chemical variation observed among populations of $E$. ruidum sp. 3-4 was particularly evident in traits involving branched and unsaturated hydrocarbons.

Within species, differences in chemical profiles are typically correlated to geographical distances. For example, distant populations $(>300 \mathrm{~km})$ of the social wasp Polistes biglumis have more divergent chemical profiles than close ones (a few tens of $\mathrm{km}$ ), although differences were typically quantitative (Bonelli et al. 2015). Our results, however, suggest that the divergence in the chemical profiles of E. ruidum sp. 3-4 might not be fully explained by geographical distance. The ants from Mazunte and Piedras Negras inhabit close geographic areas ( $<10 \mathrm{~km}$ of distance), and were considered as a single species based on mtDNA genome data (Meza-Lázaro et al. 2018), but differences in their chemical profiles exceeds the variation usually found at the intraspecific level. Therefore, factors other than geographical distance are likely to be the drivers of chemical divergence, although conclusive evidence will need extensive population sampling and focused experiments.

Cuticular hydrocarbons are typically species-specific (Lockey and Metcalfe 1988; Drijfhout et al. 2009; Guillem et al. 2016). The statistically different chemical profiles within the ants from the three populations of E. ruidum sp. 3-4 therefore support the existence of cryptic diversity in the complex. Similar examples of several chemotypes identified within single putative species were found in eusocial insects as the orchid bees of the genus Euglossa (Pokorny et al. 2014), as well as the Formica japonica (Akino et al. 2002) and Crematogaster levior and Camponotus femoratus (Hartke et al. 2019) ants, where variation in the quantities of branched hydrocarbons and unsaturated compounds unveiled hidden cryptic diversity. High intraspecific diversity was also found in the ant Formica archboldi, where different populations from Florida, USA, varied considerably in the abundance of methyl-branched cuticular compounds, matching the chemical profiles of different, sympatric species of Odontomachus ants more closely than those of conspecific populations (Smith 2019), but genetic distance among $F$. archboldi ant populations is unknown.

Overall, the cuticular traits related to branched alkanes, alkenes and alkadienes were the most variable in E. ruidum sp. 3-4 ants. These classes of compounds likely play a major role in the recognition processes in social insects, and especially in nestmate-non-nestmate discrimination (Dani et al. 2001; Châline et al. 2005; Lorenzi et al. 2011). For instance, Dani et al. (2001) showed that the supplementation of linear alkanes on alive social wasps of Polistes dominulus did not have aggression-eliciting effects on nestmates, whereas alkenes and methyl-branched alkanes did. Linear alkanes and alkenes had similar effects in Formica exsecta ants (Martin et al. 2008), where C25:1-supplemented ants were attacked by nestmates more than $n-\mathrm{C}_{25}$-supplemented ones. Linear alkanes are likely to serve mainly as waterproofing functions (Wagner et al. 2001; d'Ettorre and Lenoir 2010; van Zweden and d'Ettorre 2010), even if not exclusively (e.g. Lorenzi et al. 2004). Although sampling from a larger number of colonies would have increased the statistical power of our analyses, our 
current results on E. ruidum sp. 3-4 show that traits related to branched alkanes, alkenes and alkadienes distinguish the three different populations, whereas linear alkanes play a minor role. While E. ruidum sp. 3-4 ants have relatively similar external morphologies, they have highly diversified chemical recognition cues, and our preliminary analyses suggest that the same might be true for other taxa within the E. ruidum complex.

Environmental factors are known to affect the expression of cuticular hydrocarbons. For instance, diet changes in Linepithema humile and Acromyrmex subterraneus subterraneus ants altered chemical profiles and affected nestmate recognition (Buczkowski et al. 2005; Richard et al. 2004). On the other hand, in burying beetles (Nicrophorus vespilloides), differences in diet highlighted the importance of cuticular hydrocarbons as encoders of nutritional condition and other physiological states (Steiger et al. 2007). Also, abiotic factors such as air temperature and humidity affected the cuticular lipid layer of the fly Drosophila melanogaster (Rajpurohit et al. 2016). Although focused studies would be necessary to test the effect of abiotic factors on the cuticular chemical variation of E. ruidum sp. 3-4 ants, at present, there is no indication that the diet varies significantly among the populations under scrutiny. With respect to physical climatic parameters, our data suggest that linear alkanes (the likely most important waterproofing component of cuticular hydrocarbons) do not contribute significantly to the variation between populations. However, proportion of alkenes and methyl branched alkanes can also be affected by physical environmental conditions (Menzel et al. 2017b; Sprenger and Menzel 2020) making the link between function and hydrocarbon class less clear-cut.

Interspecific interactions have also been addressed as potentially relevant forces in the evolutionary change of cuticular hydrocarbons, both in quantitative and qualitative aspects. For example, living in association with other species (parabiosis) and not climatic factors may have promoted the evolution of chemical profiles characterized by longer hydrocarbons and higher proportions of branched alkenes and alkadienes among the ants of the genus Camponotus and Crematogaster (Menzel and Schmitt 2012; but see Sprenger et al. 2019). Similarly, the proportion of branched hydrocarbons was larger in two populations of Polistes biglumis social wasps that were infested by Polistes atrimandibularis social parasites than in a parasite-free population, while local climatic factors did not explain this divergence (Lorenzi et al. 2014). On a qualitative perspective, Formica fusca and Temnothorax longispinosus ant colonies from parasitized populations had higher cue diversity than non-parasitized ones (Martin et al. 2011; Jongepier and Foitzik 2016).

Ants of the E. ruidum complex discriminate nestmates from non-nestmates, although at different extents depending on geographic location (Breed et al. 1999). However, to our knowledge no study has tested which hydrocarbons (or which hydrocarbon classes) act as recognition cues. If branched alkanes, alkenes and alkadienes are the most important recognition cues in this ant complex, as it occurs in other social insects (van Zweden and d'Ettorre 2010), the need to distinguish between nestmates and non-nestmates may have been one of the most important pressures for the divergence of chemical cues among its species. Further studies and extended sampling are needed to test the link between local biotic and abiotic factors and $\mathrm{CHC}$ variation in this group.

The colonies of E. ruidum reach extremely high densities (Pratt 1989; Schatz and Lachaud 2008) and these ants exhibit intraspecific thievery, where specialized individuals consistently 
"forage" by stealing food from neighboring colonies (Breed et al. 1990; De Carli et al. 1998; McGlynn et al. 2015). Although in some populations these ants have a relatively permissive non-nestmate acceptance threshold (Breed et al. 1990; De Carli et al. 1998; Jandt et al. 2015), high nest density and thievery might have promoted stricter acceptance thresholds in other populations. Intruder acceptance thresholds are usually plastic and are adjusted to local food availability (d'Ettorre et al. 2004; Jandt et al. 2015), as well as thievery frequency in $E$. ruidum ants (Guénard and McGlynn 2013).

E. ruidum species complex has a broad Neotropical distribution range but to our knowledge E. ruidum sp. 3-4 ants are found only in a relatively small geographic area in the state of Oaxaca. The distribution of the E. ruidum complex of closely related species (Aguilar et al. 2016 and Meza-Lazaro et al. 2018) might reflect a mosaic sympatry (sensu Mallet et al. 2009) and be the result of non-allopatric speciation events originating from polymorphism in recognition cues. Intraspecific parasitic interactions favor genetic divergence (e.g. Savolainen and Vepsäläinen 2003) and the maintenance of variation in recognition cues (Crozier 1986). E. ruidum ants exhibit cleptobiosis (Breed et al. 1990; De Carli et al. 1998), which is a form of parasitic interactions (Breed et al. 2012; Guénard and McGlynn 2013). For the foregoing reasons, it is suggestive to draw an evolutionary scenario where high colony density and high risk of colony intrusion by intraspecific thief ants (cleptobiosis) may have promoted polymorphism in recognition cues (via disruptive selection) and this in turn may have favored genetic divergence within the species complex. This hypothesis needs to be tested in future studies exploring the association between thievery, intruder acceptance threshold and variation in cuticular hydrocarbons in different populations to explore the role of recognition cues in the speciation process.

\section{Acknowledgments}

This study is part of the PhD project of KIPC supported by a CONACyT-French government scholarship and partially funded by a grant given by DGAPA UNAM (Proyecto PAPIIT no. IN201119) and CONACyT (Programa Ciencia de Frontera convocatoria 2019, project No. 58548) to AZR and by a grant given by the Ecos-Nord-CONACYT Program (proyecto no.M12A01) to AZR and CP. Thanks to Jovanna Jasso, Sian Gadelha, Jorge Guitérrez, Carlos Santamaria and Gabriela Pérez-Lachaud for their help during the field trips in Oaxaca, México. We also thank two anonymous referees for valuable feedback on previous versions of the manuscript.

\section{Compliance with ethical standards}

\section{Conflict of interest}

The authors declare no conflict of interest. 


\section{References}

Aguilar-Velasco RG, Poteaux C, Meza-Lázaro R, Lachaud J-P, Dubovikoff D, ZaldívarRiverón A (2016) Uncovering species boundaries in the Neotropical ant complex Ectatomma ruidum (Ectatomminae) under the presence of nuclear mitochondrial paralogues. Zool J Linn Soc 178:226-240. https://doi.org/10.1111/zoj.12407

Akino T, Terayama M, Wakamura S, Yamaoka R (2002) Intraspecific variation of cuticular hydrocarbon composition in Formica japonica Motschoulsky (Hymenoptera: Formicidae). Zool Sci 19:1155-1165. https://doi.org/10.2108/zsj.19.1155

Arias-Penna TM (2008) Subfamilia Ectatomminae. In: Jiménez E, Fernández F, Arias TM, Lozano-Zambrano FH (eds) Sistemática, biogeografía y conservación de las hormigas cazadoras de Colombia. Instituto de Investigación de Recursos Biológicos Alexander von Humboldt, Bogotá, pp 53-107

Bagnères A-G, Wicker-Thomas C (2010) Chemical taxonomy with hydrocarbons. In: Blomquist GJ, Bagnères A-G (eds) Insect hydrocarbons: biology, biochemistry and chemical ecology. Cambridge University Press, Cambridge, pp 121-162

Blomquist GJ, Bagnères A-G (2010) Insect hydrocarbons: biology, biochemistry and chemical ecology. Cambridge University Press, Cambridge, UK.

Bonelli M, Lorenzi MC, Christidès J-P, Dupont S, Bagnères A-G (2015) Population diversity in cuticular hydrocarbons and mtDNA in a mountain social wasp. J Chem Ecol 41:22-31. 41:22-31. https://doi.org/10.1007/s10886-014-0531-0

Breed MD, Abel P, Bleuze TJ, Denton SE (1990) Thievery, home ranges, and nestmate recognition in Ectatomma ruidum. Oecologia 84: 117-121. https://doi.org/10.1007/BF00665604

Breed MD, Cook C, Krasnec MO (2012) Cleptobiosis in social insects. Pshyche 2022:1-7. https://doi.org/10.1155/2012/484765

Breed MD, McGlynn TP, Stocker EM, Klein AN (1999) Thief workers and variation in nestmate recognition behavior in a ponerine ant, Ectatomma ruidum. Insectes Soc 46: 327-331. https://doi.org/10.1007/s000400050153

Buczkowski G, Kumar R, Suib SL, Silverman J (2005) Diet-related modification of cuticular hydrocarbon profiles of the Argentine ant, Linepithema humile, diminishes intercolony aggression. J Chem Ecol 31:829-843. https://doi.org/10.1007/s10886-005-3547-7

Châline N, Sandoz J-C, Martin SJ, Ratnieks FLW, Jones GR (2005) Learning and discrimination of individual cuticular hydrocarbons by honeybees (Apis mellifera). Chem Senses 30:327-335. https://doi.org/10.1093/chemse/bji027

Crozier RH (1986) Genetic clonal recognition abilities in marine invertebrates must be maintained by selection for something else. Evolution 40:1100-1101. https://doi.org/10.1111/j.1558-5646.1986.tb00578.x

d'Ettorre P, Brunner E, Wenseleers T, Heinze J (2004) Knowing your enemies: seasonal dynamics of host-social parasite recognition. Naturwissenschaften 91:594-597. https://doi.org/10.1007/s00114-004-0573-1 
d'Ettorre P, Lenoir A (2010) Nestmate recognition. In: Lach L, Parr CL, Abbott KL (eds) Ant ecology. Oxford University Press, pp 194-209

Dani FR, Jones GR, Destri S, Spencer SH, Turillazzi S (2001) Deciphering the recognition signature within the cuticular chemical profile of paper wasps. Anim Behav 62:165-171. https://doi.org/10.1006/anbe.2001.1714

De Carli P, Lachaud J-P, Beugnon G, López-Méndez AJ (1998) Études en milieu naturel du comportement de cleptobiose chez la fourmi néotropicale Ectatomma ruidum (Hymenoptera, Ponerinae). Actes Coll Insectes Soc 11:29-32

Drijfhout FP, Kather R, Martin SJ (2009) The role of cuticular hydrocarbons in insects. In: Zhang W, Liu H (eds) Behavioral and chemical ecology. Nova Science Publishers Inc, New York, pp 91-114

Elmes GW, Akino T, Thomas JA, Clarke RT, Knapp JJ (2002) Interspecific differences in cuticular hydrocarbon profiles of Myrmica ants are sufficiently consistent to explain host specificity by Maculinea (large blue) butterflies. Oecologia 130:525-535. https://doi.org/10.1007/s00442-001-0857-5

Guénard B, McGlynn TP (2013) Intraspecific thievery in the ant Ectatomma ruidum is mediated by food availability. Biotropica 45:497-502. https://doi.org/10.1111/btp.12031

Guillem RM, Drijfhout FP, Martin SJ (2012) Using chemo-taxonomy of host ants to help conserve the large blue butterfly. Biol Conserv 148:39-43. https://doi.org/10.1016/j.biocon.2012.01.066

Guillem RM, Drijfhout FP, Martin SJ (2016) Species-specific cuticular hydrocarbon stability within European Myrmica ants. J Chem Ecol 42:1052-1062. https://doi.org/10.1007/s10886-016-0784-x

Hamilton WD (1987) Discrimination nepotism: expectable, common, overlooked. In: Fletcher DJC, Michener CD (eds) Kin Recognition in Animals. Wiley, New York, pp 417-437

Hammer Ø, Harper DAT, Ryan PD (2001) PAST: Paleontological statistics software package for education and data analysis. Paleontol Electron 4:9-18.

Hartke J, Sprenger PP, Sahm J, Winterberg H, Orivel J, Baur H, Beuerle T, Schmitt T, Feldmeyer B, Menzel F (2019) Cuticular hydrocarbons as potential mediators of cryptic species divergence in a mutualistic ant association. Ecol Evol 9:9160-9176. https://doi.org/10.1002/ece3.5464

Heethoff M, Laumann M, Weigmann G, Raspotnig G (2011) Integrative taxonomy: combining morphological, molecular and chemical data for species delineation in the parthenogenetic Trhypochthonius tectorum complex (Acari, Oribatida, Trhypochthoniidae). Front Zool 8:2. https://doi.org/10.1186/1742-9994-8-2

Hölldobler B, Michener CD (1980) Mechanisms of identification and discrimination in social Hymenoptera. In: Markl H (ed) Evolution of social behavior: hypotheses and empirical tests. Verlag Chemie, Weinheim, pp 35-58 
Jandt JM, Hunt EM, McGlynn TP (2015) Intraspecific food-robbing and neighborhood competition: consequences for anti-robber vigilance and colony productivity. Biotropica 47:491-496. http://dx.doi.org/10.1111/btp.12234

Jeral JM, Breed MD, Hibbard BE (1997) Thief ants have reduced quantities of cuticular compounds in a ponerinae ant, Ectatomma ruidum. Physiol Entomol 22:207-211. https://doi.org/10.1111/j.1365-3032.1997.tb01160.x

Jongepier E, Foitzik S (2016) Ant recognition cue diversity is higher in the presence of slavemaker ants. Behav Ecol 27:304-311. https://doi.org/10.1093/beheco/arv153

Kather R, Martin SJ (2012) Cuticular hydrocarbon profiles as a taxonomic tool: advantages, limitations and technical aspects. Physiol Entomol 37:25-32. https://doi.org/10.1111/j.1365-3032.2011.00826.x

Kugler C, Brown WL Jr (1982) Revisionary \& other studies on the ant genus Ectatomma, including the descriptions of two new species. Search: Agriculture 24:1-8

Lachaud J-P (1985) Recruitment by selective activation: an archaic type of mass recruitment in a ponerine ant (Ectatomma ruidum). Sociobiology 11:133-142

Lachaud J-P (1990) Foraging activity and diet in some neotropical ponerinae ants. I. Ectatomma ruidum Roger (Hymenoptera, Formicidae). Folia Entomol Mex 78:241-256.

Lachaud J-P, Cadena A, Schatz B, Pérez-Lachaud G, Ibarra-Núñez G (1999) Queen size dimorphism and reproductive capacity in the ponerine ant, Ectatomma ruidum Roger. Oecologia 120:515-523. https://doi.org/10.1007/s004420050885

Leonhardt SD, Menzel F, Nehring V, Schmitt T (2016) Ecology and evolution of communication in social insects. Cell 164:1277-1287. https://doi.org/10.1016/j.cell.2016.01.035

Lockey KH, Metcalfe NB (1988) Cuticular hydrocarbons of adult Himatismus species and a comparison with 21 other species of adult tenebrionid beetle using multivariate analysis. Comp Biochem Physiol 91:371-382. https://doi.org/10.1016/0305-0491(88)90156-3

Lorenzi MC, Sledge MF, Laiolo P, Sturlini E, Turillazzi S (2004) Cuticular hydrocarbon dynamics in young adult Polistes dominulus (Hymenoptera: Vespidae) and the role of linear hydrocarbons in nestmate recognition systems. J Insect Physiol 50:935-941. https://doi.org/10.1016/j.jinsphys.2004.07.005

Lorenzi MC, Cervo R, Bagnères A-G (2011) Facultative social parasites mark host nests with branched hydrocarbons. Anim 82:1143-1149. https://doi.org/10.1016/j.anbehav.2011.08.011

Lorenzi MC, Azzani L, Bagnères A-G (2014) Evolutionary consequences of deception: Complexity and informational content of colony signature are favored by social parasitism. Curr Zool 60:137-148. https://doi.org/10.1093/czoolo/60.1.137

Lucas C, Fresneau D, Kolmer K, Heinze J, Delabie JHC, Pho DB (2002) A multidisciplinary approach to discriminating different taxa in the species complex Pachycondyla villosa (Formicidae). Biol J Linn Soc 75:249-259. https://doi.org/10.1046/j.10958312.2002.00017.x 
Mallet J, Meyer A, Nosil P, Feder JL (2009) Space, sympatry and speciation. J Evol Biol 22: 2332-2341. https://doi.org/10.1111/j.1420-9101.2009.01816.x

Magnacca KN, Brown MJ (2010) Mitochondrial heteroplasmy and DNA barcoding in Hawaiian Hylaeus (Nesoprosopis) bees (Hymenoptera: Colletidae). BMC Evol Biol 10:174. https://doi.org/10.1186/1471-2148-10-174

Martin SJ, Vitikainen E, Helanterä H, Drijfhout FP (2008) Chemical basis of nest-mate discrimination in the ant Formica exsecta. Proc R Soc B 275:1271-1278. https://doi.org/10.1098/rspb.2007.1708

Martin SJ, Helanterä H, Drijfhout F (2011) Is parasite pressure a driver of chemical cue diversity in ants?. Proc R Soc B 278:496-503. https://doi.org/10.1098/rspb.2010.1047

McGlynn TP, Graham R, Wilson J, Emerson J, Jandt JM, Jahren AH (2015) Distinct types of foragers in the ant Ectatomma ruidum: typical foragers and furtive thieves. Anim Behav 109:243-247. https://doi.org/10.1016/j.anbehav.2015.08.024

Menzel F, Schmitt T (2012) Tolerance requires the right smell: first evidence for interspecific selection on chemical recognition cues. Evolution 66-3:896-904. https://doi.org/10.1111/j.1558-5646.2011.01489.x

Menzel F, Schmitt T, Blaimer BB (2017a) The evolution of a complex trait: cuticular hydrocarbons in ants evolve independent from phylogenetic constraints. J Evol Biol 30:1372-1385. https://doi.org/10.1111/jeb.13115

Menzel F, Blaimer B, Schmitt T (2017b) How do cuticular hydrocarbons evolve? Physiological constraints and climatic and abiotic selection pressures act on a complex functional trait. Proc R Soc B 284:20161727. http://dx.doi.org/10.1098/rspb.2016.1727

Meza-Lázaro RN, Poteaux C, Bayona-Vásquez NJ, Branstetter MG, Zaldívar-Riverón A. (2018) Extensive mitochondrial heteroplasmy in the neotropical ants of the Ectatomma ruidum complex (Formicidae: Ectatomminae). Mitochondrial DNA A. https://doi.org/10.1080/24701394.2018.1431228

Miller MA, Pfeiffer W, Schwartz T (2010) Creating the CIPRES science gateway for inference of large phylogenetic trees. In Proc Gateway Computing Environments Workshop (GCE), 2010, LA, pp 1-8

Pokorny T, Lunau K, Quezada-Euan JJG, Eltz T (2014) Cuticular hydrocarbons distinguish cryptic sibling species in Euglossa orchid bees. Apidologie 45, 276-283. https://doi.org/10.1007/s13592-013-0250-5

Pratt SC (1989) Recruitment and other communication behavior in the ponerine ant Ectatomma ruidum. Ethology 81:313-331. https://doi.org/10.1111/j.14390310.1989.tb00777.x

Rajpurohit S, Hanus R, Vrkoslav V, Behrman EL, Bergland AO, Petrov D, Cvačka J, Schmidt PS (2017) Adaptive dynamics of cuticular hydrocarbons in Drosophila. J Evol Biol 30: 66-80. https://doi.org/10.1111/jeb.12988 
Richard F-J, Hefetz A, Christidès J-P, Errard C (2004) Food influence on colonial recognition and chemical signature between nestmates in the fungus-growing ant Acromyrmex subterraneus subterraneus. Chemoecology 14:9-16. https://doi.org/10.1007/s00049-0030251-3

Rzedowski J (2006) Vegetación de México. 1ra edición digital. Comisión Nacional para el Conocimiento y Uso de la Biodiversidad, México

Savolainen R, Vepsäläinen K (2003) Sympatric speciation through intraspecific social parasitism. PNAS 100: 7169-7174. https://doi.org/10.1073/pnas.1036825100

Schatz B, Lachaud J-P (2008) Effect of high nest density on spatial relationships in two dominant Ectatommine ants (Hymenoptera: Formicidae). Sociobiology 51:623-643

Schlick-Steiner BC, Steiner FM, Moder K, Seifert B, Sanetra M, Dyreson E, Stauffer C, Christian E (2006) A multidisciplinary approach reveals cryptic diversity in Western Paleartic Tetramorium ants (Hymenoptera: Formicidae). Mol Phylogenet Evol 40:259273. https://doi.org/10.1016/j.ympev.2006.03.005

Smith AA (2019) Prey specialization and chemical mimicry between Formica archboldi and Odontomachus ants. Insectes Soc 66:211-222. https://doi.org/10.1007/s00040-018-0675$\mathrm{y}$

Sprenger PP, Hartke J, Feldmeyer B, Orivel J, Schmitt T, Menzel F (2019) Influence of mutualistic lifestyle, mutualistic partner, and climate on cuticular hydrocarbon profiles in parabiotic ants. J Chem Ecol 45:741-754. https://doi.org/10.1007/s10886-019-01099-9

Sprenger PP, Menzel F (2020) Cuticular hydrocarbons in ants (Hymenoptera: Formicidae) and other insects: how and why they differ among individuals, colonies, and species. Myrmecol News 30:1-26. https://doi: 10.25849/myrmecol.news_030:001

Stamatakis A (2014) RAxML version 8: a tool for phylogenetic analysis and post-analysis of large phylogenies. Bioinformatics 30:1312-1313. https://doi.org/10.1093/bioinformatics/btu033

Steiger S, Peschke K, Francke W, Müller JK (2007) The smell of parents: breeding status influences cuticular hydrocarbon pattern in the burying beetle Nicrophorus vespilloides. Proc R Soc B Biol 274:2211-2220. https://doi.org/10.1098/rspb.2007.0656

Steiner FM, Csősz S, Markó B, Gamisch A, Rinnhofer L, Folterbauer C, Hammerle S, Stauffer C, Arthofer W, Schlick-Steiner BC (2018) Turning one into five: Integrative taxonomy uncovers complex evolution of cryptic species in the harvester ant Messor "structor" Mol Phylogenetics $\quad$ Evol 127:387-404. https://doi.org/10.1016/j.ympev.2018.04.005

van Zweden JS, d'Ettorre P (2010) Nestmate recognition in social insects and the role of hydrocarbons. In: Blomquist GJ, Bagnères A-G (eds) Insect hydrocarbons: biology, biochemistry and chemical ecology. Cambridge University Press, Cambridge, pp 222 243 
Wagner D, Tissot M, Gordon D (2001) Task-related environment alters the cuticular hydrocarbon composition of harvester ants. J Chem Ecol 27:1805-1819. https://doi.org/10.1023/A:1010408725464

Wyatt TD (2014) Pheromones and Animal Behavior: Chemical Signals and Signatures. Cambridge University Press, Cambridge. 


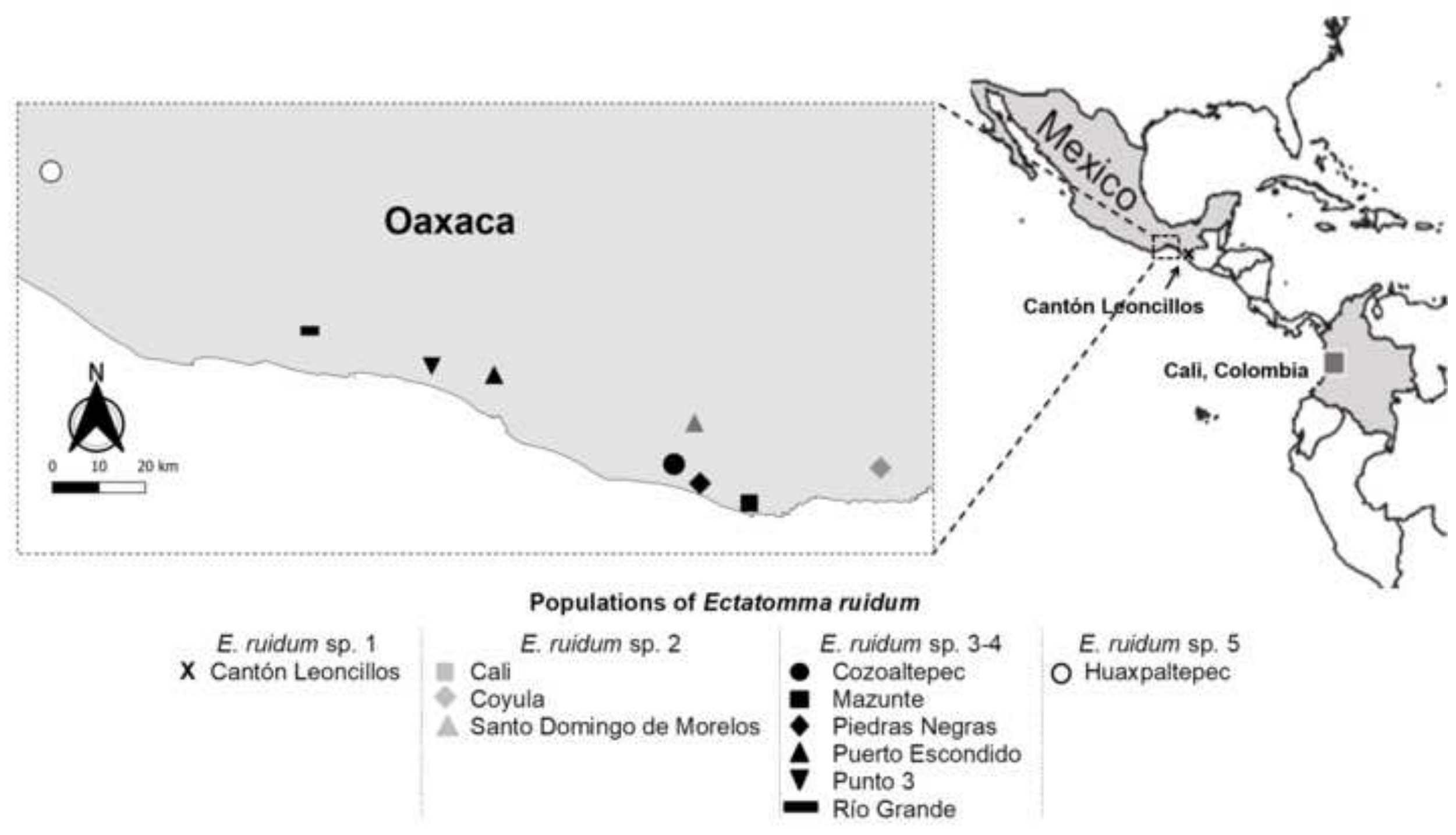

Populations of Ectatomma ruidum

\begin{tabular}{|c|c|c|c|}
\hline $\begin{array}{c}\text { E. ruidum sp. } 1 \\
\mathbf{X} \text { Cantón Leoncillos }\end{array}$ & $\begin{array}{l}\quad \text { E. ruidum sp. } 2 \\
\text { Cali } \\
\text { Coyula } \\
\text { A Santo Domingo de Morelos }\end{array}$ & $\begin{array}{ll} & \text { E. ruidum sp. } 3-4 \\
\text { - } & \text { Cozoaltepec } \\
& \text { Mazunte } \\
& \text { Piedras Negras } \\
\mathbf{\nabla} & \text { Puerto Escondido } \\
\text { Punto } 3 \\
\text { Rio Grande }\end{array}$ & $\begin{array}{l}\text { E. ruidum sp. } 5 \\
\text { O Huaxpaltepec }\end{array}$ \\
\hline
\end{tabular}



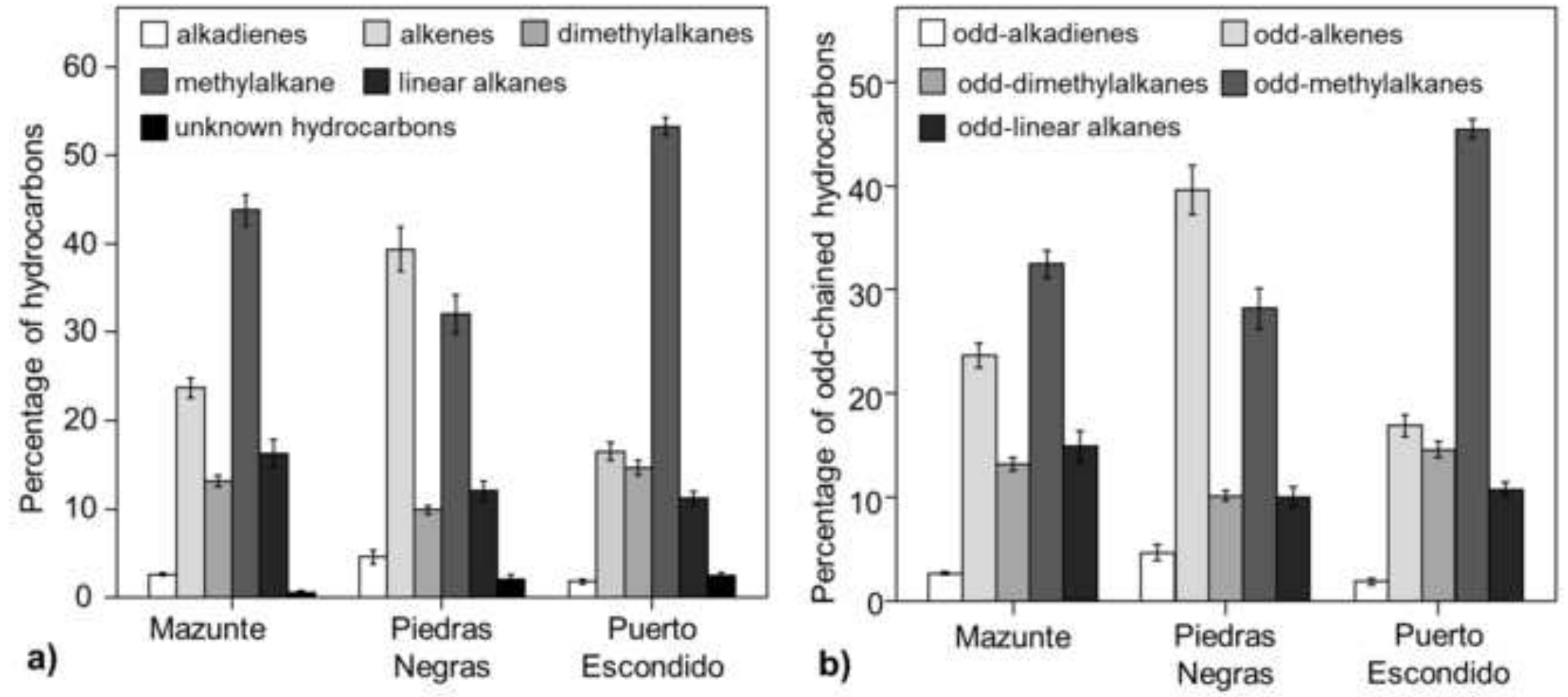


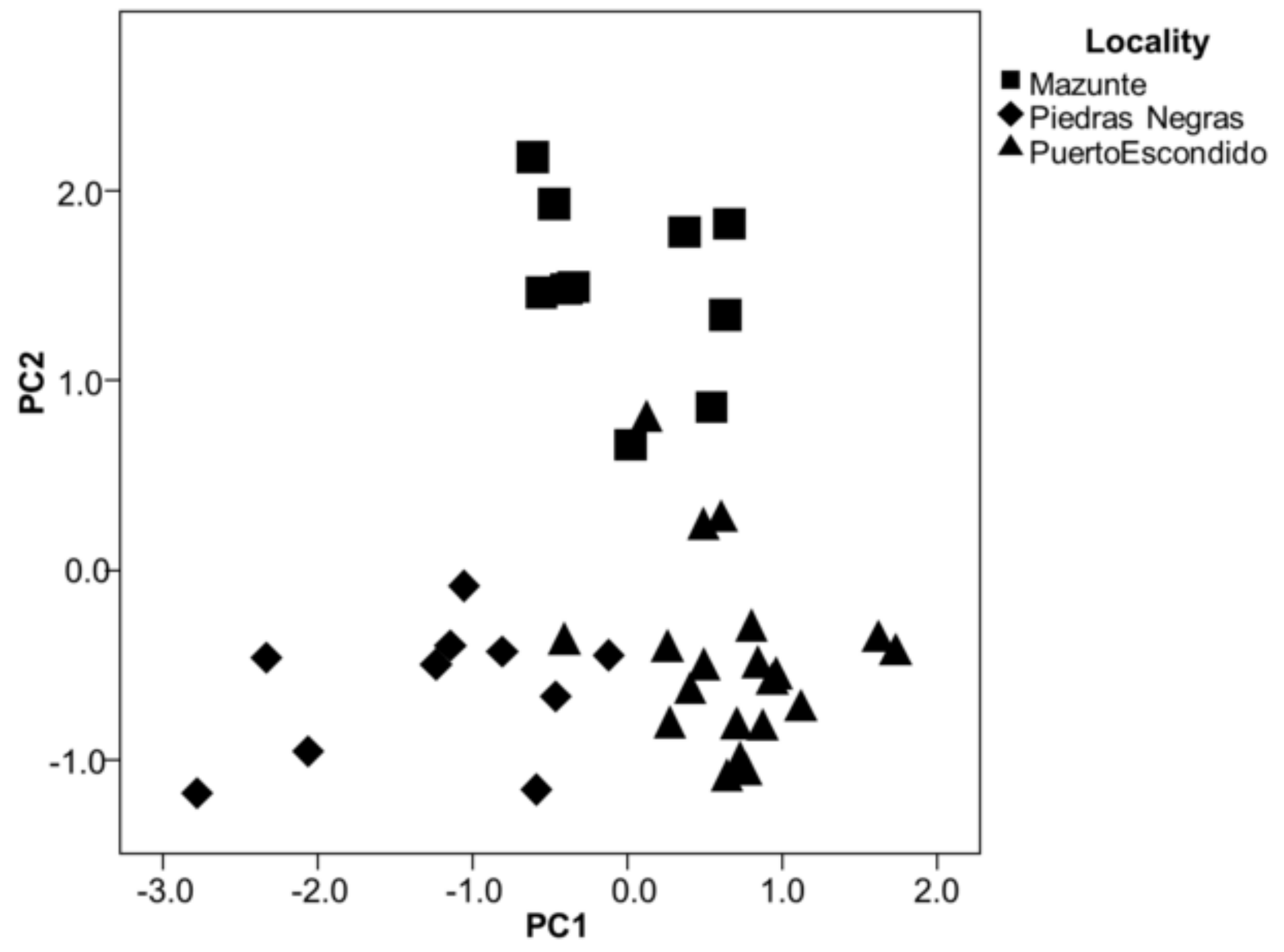




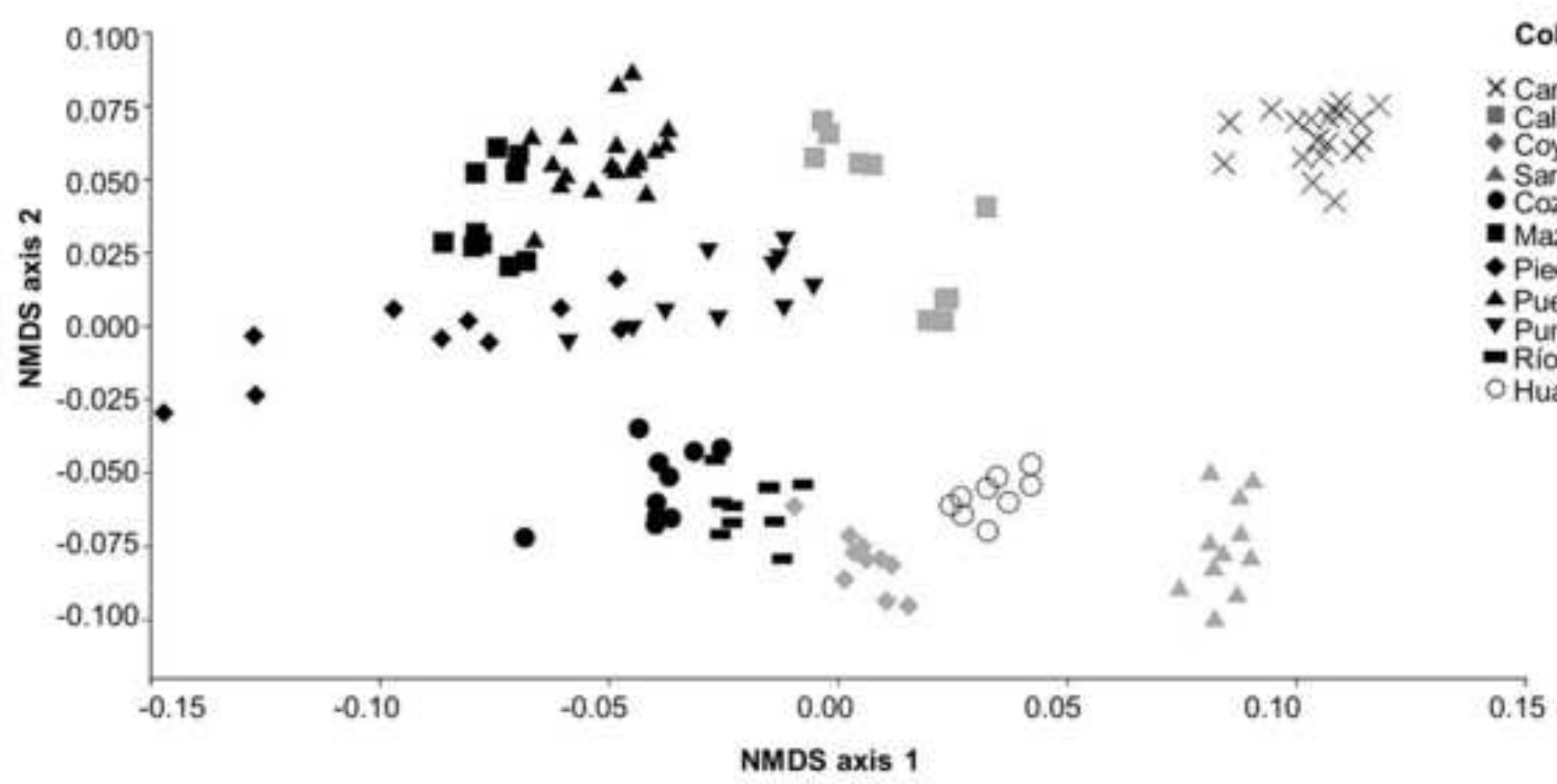

Cantón Leoncillos, E. ruidum sp. 1 Cali, sp. 2

Coyula, sp. 2

Santo Domingo de Morelos, sp. 2

cozoaltepec, sp. 3-4

Mazunte, sp. 3-4

- Piedras Negras, sp. 3-4

Puerto Escondido, sp. 3-4

Punto 3, sp. 3-4

Río Grande, sp. 3-4

Huaxpaltepec, sp. 5

NMDS axis 1 
Click here to access/download attachment to manuscript SM1.pdf 
Click here to access/download SM2.pdf

\section{attachment to manuscript}

